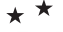

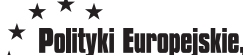

$\star$ Finanse i Marketing

$\star \star \star 15(64) 2016$

Mariusz Grębowiec

Szkoła Glówna Gospodarstwa Wiejskiego w Warszawie

\title{
Rola marki w procesie podejmowania decyzji zakupu produktów mleczarskich na przykładzie rynku jogurtów
}

\section{THE ROLE OF BRAND IN THE PURCHASE DECISION MAKING OF DAIRY PRODUCTS FOR EXAMPLE YOGHURT MARKET}

\begin{abstract}
Produkty wysokiej jakości ciesza się uznaniem wśród konsumentów. Nieustajaca analiza preferencji i wyborów nabywców pozwala na dostrzeganie zmian $w$ zachowaniach rynkowych, a także wskazuje przedsiębiorstwom kierunki rozwoju. Uwzględnianie tych preferencji $w$ działaniach przedsiębiorstw wpływa na wzrost ich pozycji rynkowej, a także na pozyskiwanie coraz większej liczby lojalnych nabywców. Marka spetnia istotna role podczas dokonywania wyboru spośród szerokiego wachlarza ofert rynkowych. Lojalność nabywców wobec marki wplywa więc na zwiększanie się jej renomy. Przekłada się to również na wzrost sprzedaży oraz możliwość dalszego rozwoju firmy. Znane marki moga konkurować jakościq o lojalność klientów. Wykorzystujac strategie kreowania wizerunku marki, zyskuje ona przewage konkurencyjnq.

Celem opracowania byto określenie znaczenia marki podczas zakupu produktów mleczarskich. Jako główne spektrum zainteresowania wybrany został rynek mleka oraz jego przetworów, ze szczególnym uwzględnieniem rynku jogurtów. $W$ opracowaniu zebrano rozważania teoretyczne $z$ zakresu marki $i$ czynników warunkujacych jej siłę, ponadto przedstawiono wspótczesna sytuację na rynku mleka oraz jego przetworów. Rozważania teoretyczne poparto badaniami przeprowadzonymi wśród 250 przypadkowo dobranych respondentów. Osiagnięte wyniki badań pozwolity na wyciagniecie wniosków zawartych na końcu opracowania. Z przeprowadzonych badań wynika, że marka ma istotne znaczenie $w$ procesie zakupu jogurtów. Wysoka jakość produktów markowych wptywa na zaufanie konsumentów do marki, a wzrost lojalności nabywców przekłada się na wzrost sprzedaży i umocnienie pozycji rynkowej przedsiębiorstwa. Producenci jogurtów, posiadajacy markę cieszqca się uznaniem, powinni $w$ swoich działaniach kierować się dobrem konsumenta, gdyż od jego wyborów zależy dalszy rozwój wizerunku marki $i$ przedsiębiorstwa także $w$ wymiarze ekonomicznym.
\end{abstract}

Słowa kluczowe: marka, branża mleczarska, jogurt. 


\section{Wstęp}

Problematyka marki ma coraz większe znaczenie we współczesnym marketingu. Ma ona charakter interdyscyplinarny, gdyż marka jest przedmiotem zainteresowania specjalistów wielu dziedzin nauki, m.in. ekonomistów, psychologów, a nawet plastyków.

Współczesne przedsiębiorstwa przywiązują dużą wagę do roli odgrywanej przez markę. Wiążę się to bezpośrednio z powstawaniem coraz nowszych produktów, zastępowaniem jednych produktów ich substytutami, co przekłada się na wysoką konkurencję. Przedsiębiorstwa więc muszą dążyć do wypromowania swojej marki, dzięki której mogą osiagnąć stabilną pozycję rynkową. Ważne jest także, znalezienie i zdefiniowanie atrybutów silnej marki. Pozwala to na trafne kształtowanie strategii marki, co ma wpływ na budowanie świadomości marki wśród konsumentów w procesie zakupu. Znajomość marki wpływa także na powiązywanie jej z jakością, jak również na wzrost lojalności, który będzie miał odzwierciedlenie w wysokości sprzedaży i nastawieniu konsumentów do danego przedsiębiorstwa.

\section{Marka i czynniki decydujące o sile jej rynkowego oddziaływania}

Jedną $\mathrm{z}$ najpopularniejszych i najczęściej cytowanych definicji marki jest definicja $\mathrm{Ph}$. Kotlera, według której marka określana jest jako: „nazwa, znak, symbol, wzór lub kombinacja tych elementów; nadana przez sprzedawce (...) w celu identyfikacji dobra lub ustugi oraz ich wyróżnienia na tle produktów konkurencyjnych" ". Według słownika języka polskiego PWN marka to ,,znak firmowy umieszczany na wyrobach; jakość lub gatunek wyrobów danej firmy; dobra opinia"2. Warto dostrzec, że termin marka może być odmiennie rozumiany przez różnych nabywców. Marka jest trwałym elementem, który identyfikuje producenta $\mathrm{z}$ wytwarzanym przez niego produktem. Jest nieodłączną częścią funkcjonowania przedsiębiorstwa. Stanowi podstawę do odróżnienia produktów konkretnego wytwórcy od towarów konkurencyjnych. Dzięki marce przedsiębiorstwa mogą budować przewagę konkurencyjną.

Wizerunek maki budowany jest długofalowo przez przedsiębiorstwo, co wpływa na niemożność natychmiastowego jego naśladownictwa przez rywali rynkowych ${ }^{3}$. Siła marki jest związana z jej pozycją rynkową. Rozumiana jest jako popyt na daną markę w stosunku do popytu na towary konkurencyjne ${ }^{4}$. To jak postrzegana będzie marka na tle rywali rynkowych zależy od jej indywidualnych cech.

Atrybut marki to ,cechy lub oznaczenie marki pozwalajace na jej odróżnienie od innych", O konkurencyjności produktu decydują złożone elementy, które tworzą spójną całość. Nieefektywność jednego z nich może przyczynić się do niepowodzenia marki za sprawą braku akceptacji wśród konsumentów. Zasadniczymi atrybutami silnej marki są

- Wizerunek marki,

\footnotetext{
${ }^{1}$ Kotler Ph., Armstrong G., Saunders J., Wong V., Marketing. Podręcznik akademicki, Polskie Wydawnictwo Ekonomiczne, Warszawa 2002, s. 626.

${ }^{2}$ Stownik Języka Polskiego, PWN, http://sjp.pwn.pl/sjp/marka-I;2481355.html (dostęp z dn. 27.12.2014r.)

${ }^{3}$ A. Rudzewicz, Rola i znaczenie zaufania w kreowaniu marki, „Marketing i Rynek”, 2014, nr 8, s. 645.

${ }^{4}$ M. K. Witek-Hajduk, Zarzadzanie..., dz. cyt., s. 39.

${ }^{5}$ Grzegorczyk A., Reklama, Polskie Wydawnictwo Ekonomiczne, Warszawa 2010, s. 68.

${ }^{6}$ M. K. Witek-Hajduk, Zarzadzanie..., dz. cyt., s. 39.
} 
- Jakość dostrzegana przez nabywców,

- Lojalność wobec marki,

- Ś́siadomość (znajomość) marki,

Wizerunek marki jest subiektywnym obrazem marki, który pojawia się $\mathrm{w}$ świadomości nabywców. Uzależniony jest on od indywidualnych cech konsumentów ${ }^{7}$. Silna marka wyróżnia się bezkonkurencyjnym wizerunkiem, który wpływa na powszechną jej akceptację. Konsument $\mathrm{w}$ procesie zakupowym wybierze tą markę, której cechy górują nad produktami konkurencji. Będzie miał też na uwadze korzyści jakie spłyną na niego dzięki nabyciu danego produktu. Na podstawie skojarzeń konsumenci podejmują decyzje zakupowe. Ogólna ocena jest wynikiem różnorodnych elementów i wpływa na stopień pozytywnej oceny wizerunku marki ${ }^{8}$.

Jakość marki jest oceniana indywidualnie przez nabywców. Produkty markowe mogą realnie charakteryzować się inną jakością, niż według opinii nabywców.

Zauważana przez nabywców jakość może podnosić wartość marki. Zwiększa częstotliwość zakupu danego produktu przez pomoc w dokonywaniu wyboru pomiędzy alternatywami. Wpływa także na odpowiednie klasowanie produktów i uszeregowanie ich np. w grupie produktów luksusowych. W ramach myślenia stereotypowego jakość marki wiąże się z wyższą ceną, dlatego może wpłynąć to na podwyższenie jego ceny, co zwiększa przychody przedsiębiorstw. Produkty o postrzeganej wysokiej jakości przyciągają uwagę hurtowników, gdyż taki produkt zwiększa atrakcyjność ich ofert ${ }^{9}$.

Znajomość marki to zdolność do jej rozpoznania lub przypomnienia i świadomość kategorii produktów jaką ona reprezentuje.

Wyodrębnia się cztery stopnie znajomości marki wśród nabywców ${ }^{10}$ :

- Nieznajomość marki- konsument nie jest w stanie, ani rozpoznać, ani przypomnieć sobie marki podczas dokonywania zakupu,

- Wspomagana znajomość marki- konsument rozpoznaje markę dopiero po pokazaniu mu kilku innych marek. Wtedy potrafi już przyporządkować ją do odpowiedniej grupy,

- Spontaniczna znajomość marki- konsument nie uzyskując jakiejkolwiek pomocy wskazuje grupę marek w określonej mu kategorii,

- Marka wskazana jako pierwsza- konsument wśród danej kategorii wymienia markę jako pierwszą. Może też wymienić ją jako jedyną $\mathrm{z}$ danej grupy produktów.

Znajomość marki jest podstawą do pojawienia się w konsumencie szeregu skojarzeń z nią powiązanych. Przyczynia się także do włączenia jej do koszyka wariantów spośród których konsument wybierze oczekiwany produkt.

\footnotetext{
${ }^{7}$ Tamże, s. 40.

${ }^{8}$ M. Dębski, Kreowanie silnej marki, Polskie Wydawnictwo Ekonomiczne, Warszawa 2009, s. 15.

${ }^{9}$ Urbanek G., Zarzadzanie markq, Polskie Wydawnictwo Ekonomiczne, Warszawa 2002, s. 46-46.

${ }^{10}$ Witek - Hajduk M. K., Zarzadzanie silnq markq, Wyd. Oficyna a Wolters Kulwer business, Warszawa 2011, s. 50 .
} 


\section{Rynek mleka i jego przetworów w Polsce}

Produkcja mleka w Polsce jest gałęzią produkcji rolniczej, którą uważa się za jedną z najważniejszych ${ }^{11}$. W przeciwieństwie do produkcji roślinnej jest ona źródłem stałego dochodu rolniczego ${ }^{12}$.

Rynek mleka cechuje niejednolitość oraz różnorodność segmentów i ich specyfika $^{13}$. Uwarunkowane jest to przez różnorodne potrzeby konsumentów co do jakości, poziomu cen oraz różnorodności asortymentu. Niejednolity rynek warunkuje też specyfika branży. Bogata struktura asortymentowa wpływa na różnorodność procesów produkcyjnych, co przyczynia się do powstawania odrębnych segmentów w obrębie branży.

Polska jest jednym z czołowych producentów mleka w Unii Europejskiej. W kraju wytwarza się około $8 \%$ całkowitej produkcji całej wspólnoty. W strukturze krajowej, globalnej produkcji rolniczej, udział produkcji mleka waha się w granicach 12$15 \%{ }^{14}$. Liczba mleczarni w Polsce nadal spada. W 2014 roku liczba zakładów wynosiła 176, czyli o 18 zakładów mniej w porównaniu do 2011 roku. Zmniejsza się także liczba osób zatrudnionych w tych zakładach. Spadek liczby zakładów nie oznacza jednak spadku wartości sprzedaży. Ciąłły wzrost sprzedaży przy jednoczesnym zmniejszeniu liczby zakładów oznacza natomiast, że rośnie wydajność produkcyjna jednostek oraz poprawie ulega technologiczny poziom przetwórstwa. W 2014 roku uznano za rentowne $63 \%$ firm mleczarskich, co wykazuje jednak tendencję spadkową w stosunku do roku 2012, kiedy to udział firm rentownych wynosił ponad 70\%. Wśród zakładów przetwórczych zaobserwowany został także narastający proces koncentracji $1^{15}$.

Wraz z wstapieniem Polski do Unii Europejskiej nastąpił proces modernizacji polskich przetwórni mleczarskich. Przetwórnie krajowe cechują się współcześnie wysokim poziomem technologicznym. Przestrzegane są w nich bardzo wysokie standardy higieny w procesach produkcyjnych. Istotną kwestią jest bowiem zachowanie wysokiej jakości produktów ${ }^{16}$. Przemysł mleczarski nieustannie ulega przemianom dostosowując się do ciągle zmieniającej się sytuacji na rynku, która jest wynikową zmieniających się preferencji konsumenckich.

\footnotetext{
${ }^{11}$ J. Kossakowska, J. Sych- Winiarek, E. Bochlińska, Spożycie przetworów mleczarskich w Polsce na tle zmian w podaży mleka, ,Biuletyn Informacyjny”, ARR, Warszawa 2013, nr 4, s. 4.

${ }^{12} \mathrm{M}$. Świątkowska, Mleko - podstawa diety i gospodarki żywnościowej, „Biuletyn Informacyjny”, ARR, Warszawa 2014, nr 3, s. 2.

${ }^{13}$ Tamże, s. 5.

${ }^{14}$ Tamże, s. 4.

${ }^{15}$ Rynek mleka, stan i perspektywy. Analizy rynkowe, IERiGŻ, ARR i MRiRW, wrzesień 2015, s. 15

16 Tamże, s. 16.
} 


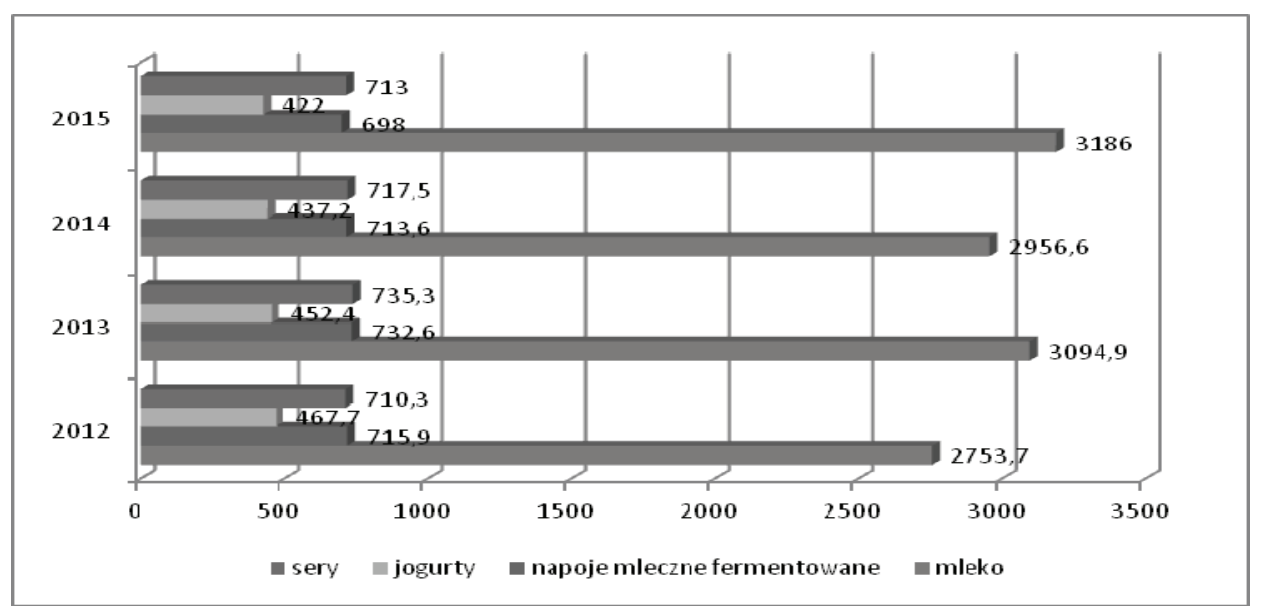

Rysunek 1. Produkcja mleka i jego przetworów w Polsce w latach 2012-2015 (w tys. ton).

Opracowanie własne na podstawie: Rynek mleka, stan i perspektywy. Analizy rynkowe, IERiGŻ, ARR i MRiRW, wrzesień 2015, str. 15.

$\mathrm{Na}$ rynku mleczarskim dynamicznie zmienia się oferta asortymentowa. Zwiększa się także dostępność produktów. Poprawie ulega jakość oferowanych wyrobów oraz ich atrakcyjność. Szeroko pojęte działania marketingowe wpływają na pozytywny wizerunek artykułów mleczarskich. Przekłada się to na zmianę obrazu produktów w oczach konsumenta, co pozytywnie wpływa na jego decyzje w procesie zakupu.

\section{Spożycie mleka i artykułów mleczarskich}

Badanie budżetów gospodarstw domowych pokazuje, że najwyższym poziomem konsumpcji cechuje się mleko spożywcze. Produkt ten zajmuje czołowe miejsce pomimo dynamicznego spadku jego konsumpcji. Na kolejnym miejscu znalazły się sery twarogowe, a kolejno za nimi jogurty. Taka tendencja może się nieznacznie różnić $\mathrm{w}$ analizach szczegółowych, które uwzględniają zależności społeczne oraz ekonomiczne ${ }^{17}$.

Według danych Głównego Urzędu Statystycznego poziom spożycia bilansowego mleka kształtował się na poziomie 205 1/mieszkańca w 2014 roku. Konsumpcja mleka jest mniejsza o około $30 \%$ w stosunku do jego spożycia w pozostałych krajach członkowskich $\mathrm{UE}^{18}$.

Spożycie mleka na przełomie 2010 - 2014 roku spadło o 0,211 na osobę. Co wiązać się mogło ze zmniejszeniem przeciętnych wydatków miesięcznych na mleko w gospodarstwach domowych. Pierwszy kwartał 2014 roku przyniósł jednak nieznaczny wzrost tych wydatków, co może przełożyć się jednocześnie na zwiększenie spożycia mleka oraz przetworów mleczarskich. Spadek spożycia mleka zauważa się we wszystkich rodzajach gospodarstw domowych (pracownicy, rolnicy, pracujący na własny rachunek, emeryci i renciści). Najwyższy poziom spożycia odnotowano w grupie

\footnotetext{
${ }^{17}$ Tamże, s. 16.

${ }^{18}$ M. Świątkowska, Mleko..., dz. cyt., s. 5.
} 
rolników i wynosi on 4,46 1/ osobę w 2014 roku, zaś najniższym poziomem spożycia charakteryzuje się grupa pracowników z wielkością przeciętnego spożycia 2,91 1/osobę.

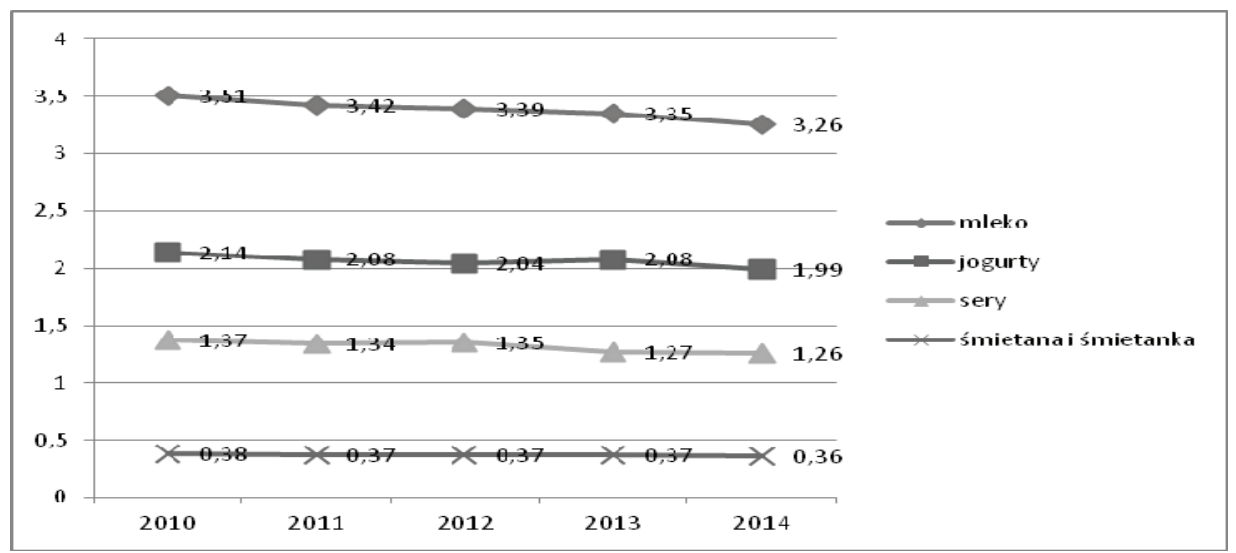

Rysunek 2. Spożycie mleka i jego przetworów w gospodarstwach domowych w 1/kg/1os. w latach 2010-2014. Opracowanie własne na podstawie: Rynek mleka, stan i perspektywy. Analizy rynkowe, IERiGŻ, ARR i MRiRW, wrzesień 2015, str. 19

Pomimo ogólnego spadku konsumpcji artykułów mleczarskich, przeciętne miesięczne spożycie jogurtów na przestrzeni 2010 - 2014 roku utrzymywało się na podobnym poziomie wykazując jednak niewielką tendencję spadkową ( z $0,54 \mathrm{~kg}$. W 2010 do $0,5 \mathrm{~kg} \mathrm{w}$ roku 2014) ${ }^{19}$.

W gospodarstwach domowych spożycie jogurtów zwiększyło się o $58 \%$ biorąc pod uwage lata 2000-2012. Wzrost wywołało znaczące i ciagle rosnące zainteresowanie zdrowym trybem życia. Jogurty są postrzegane jako produkt będący istotnym elementem urozmaiconej, zdrowej diety ${ }^{20}$. Porównując spożycie krajowe do jego światowego poziomu Polska nie plasuje się w ścisłej czołówce. Jogurty cieszą się znaczną popularnością na świecie. Konsumpcja tych produktów sięga 21,3 kg/osobę we Francji, $13,2 \mathrm{~kg} / \mathrm{osobę} \mathrm{w} \mathrm{Irlandii} \mathrm{i} \mathrm{12,4} \mathrm{kg/osobę} \mathrm{w} \mathrm{Kanadzie}{ }^{21}$.

Światowa konsumpcja jogurtów wzrosła w ciagu ostatnich 3 lat. Jak podaje International Yoghurt Survey jest to produkt spożywany najczęściej w porze śniadaniowej. Szacuje się, że $60 \%$ osób poddanych badaniu sięga po jogurty ponad 3 razy w tygodniu ${ }^{22}$.

W Polsce konsumpcja jogurtów bezpośrednio wiąże się z ilością spożywanego mleka oraz ogólnokrajowym poziomem konsumpcji wyrobów mleczarskich. Poziom spożycia zmienia się wraz ze zmianą stylu życia Polaków. W przeciwieństwie do rynków zachodnioeuropejskich $\mathrm{w}$ Polsce produkt ten traktowany jest w większym stopniu jako deser, niż jako szybka przekąska. Produkty spożywcze, a szczególnie

\footnotetext{
${ }^{19}$ Rynek mleka, stan i perspektywy. Analizy rynkowe, IERiGŻ, ARR i MRiRW, wrzesień 2015, s. 15.

${ }^{20}$ Kossakowska J., Sych - Winiarek J., Bochlińska E., Spożycie przetworów mleczarskich w Polsce na tle zmian w podaży mleka, „Biuletyn Informacyjny”, ARR, Warszawa 2013, nr 4, s. 10.

${ }^{21}$ J. Górska, Jogurty owocowe: Mistrzowskie posunięcie, „Forum Mleczarskie Handel”, 2014, nr 6, s. 67.

${ }^{22}$ Tamże.
} 
pochodzenia mleczarskiego, powinny mieć cechy, które pozytywnie wpływają na proces ich postrzegania. Według badań wpływu różnorodnych czynników na podejmowanie decyzji przez konsumentów w sklepach wynika, że w znacznym stopniu konsumenci zwracają uwagę na smak, świeżość oraz skład, a zwłaszcza zawartość tłuszczu oraz różnego rodzaju dodatki zawarte $\mathrm{w}$ produktach mleczarskich. Kwestia smaku ma największe znaczenie w procesie zakupu jogurtów oraz serów twarogowych ${ }^{23}$.

Podsumowując, obecnie na poziom spożycia artykułów mleczarskich a szczególnie jogurtów ma wpływ zróżnicowana oferta produktów, ich dynamiczna zmiana oraz szeroka i powszechna dostępność asortymentu. Istotna jest także wiedza konsumentów na temat danego produktu oraz uwarunkowania emocjonalne związane z procesem konsumpcji. Wysokie oddziaływanie ma też miejsce dokonywania zakupu.

\section{Znaczenie marki w procesie zakupu jogurtów w świetle badań}

\section{Cel i metodyka badań}

Przeprowadzone badania miały na celu określenie wpływu marki i czynników z nią związanych, na podejmowanie decyzji nabywczych na przykładzie branży mleczarskiej, a ściślej ujmując na rynku jogurtów. Zostały one przeprowadzone metodą ankiety internetowej w grupie 250 przypadkowo dobranych osób w czerwcu 2015 roku. Wśród ankietowanych $51 \%$ stanowiły kobiety, a $49 \%$ mężczyźni. Tak równomierny podział ze względu na płeć pozwolił na dostrzeżenie zmiennych zachowań w grupie kobiet oraz mężczyzn.

Grupa wiekowa 20 - 30 była najliczniejszą grupą wśród respondentów (35\%), zarówno wśród kobiet jak i wśród mężczyzn. Zaś najmniej liczną była grupa wiekowa 40 i więcej (19\%).

Wykształceniem średnim charakteryzowała się grupa 52\% respondentów. Wykształcenie wyższe posiadało $19 \%$ ankietowanych, przy czym większość stanowili mężczyźni. Najmniejszym odsetkiem badanych odznaczała się grupa ankietowanych z wykształcenie zawodowym, stanowiła ona zaledwie 5\% ogółu badanych.

Ze względu na miejsce zamieszkania, 56\% ankietowanych zamieszkiwało tereny wiejskie, zaś $44 \% \mathrm{z}$ nich była mieszkańcami miast. W większości respondenci określili swoją sytuację materialną jako dobrą lub przeciętną.

\section{Czynniki brane pod uwagę w procesie nabywczym jogurtów}

Jogurt jest artykułem spożywczym codziennego użytku. Znajduje się on w koszyku zakupowym przeciętnego konsumenta przynajmniej kilka razy w miesiącu. Wszyscy badani respondenci zadeklarowali, że są konsumentami jogurtów. Największa ich grupa (42\%) zadeklarowała, że kupuje ten produkt kilka razy w tygodniu. Jedynie $7 \%$ ankietowanych oświadczyło, iż dokonuje zakupu jogurtów rzadziej niż raz w miesiącu. Wysoka częstotliwość zakupów świadczy o popularności tych produktów oraz o częstym ich spożywaniu wśród konsumentów.

${ }^{23}$ M. Świątkowska, Mleko..., dz. cyt., s. 8-9. 


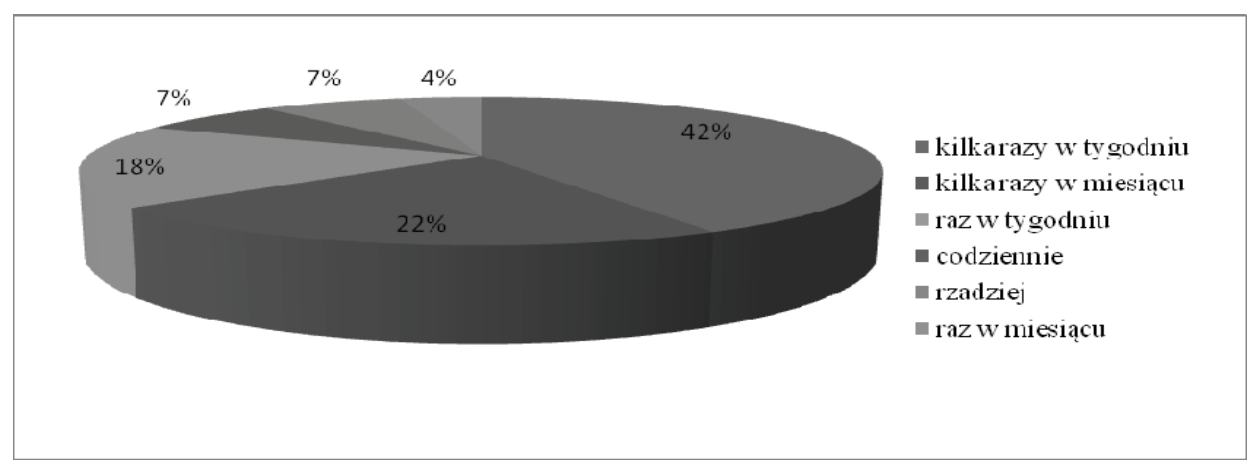

Rysunek 3. Częstotliwość zakupu jogurtów

Źródło: opracowanie własne na podstawie wyników badań

Dokonywanie zakupów w sklepach samoobsługowych pozwala konsumentom na spędzenie większej ilości czasu przed półką sklepową analizując oferowany przez producentów wachlarz artykułów mleczarskich. Najczęściej wybieranym miejscem zakupu jogurtów były właśnie sklepy samoobsługowe. Dokonuje w nich zakupów aż 77\% badanych. Mężczyźni częściej dokonują zakupów w sklepach z tradycyjną obsługą, niż kobiety. Sklepy internetowe, jako miejsce zakupu nie były wymieniane przez badanych.

Badani, podczas dokonywania zakupu zwracają uwagę na szereg cech funkcjonalnych, dzięki którym mogą dokonać stosownego wyboru. Kluczową cechą jogurtu, która skłania konsumenta do zakupu jest jego smak (57\%) oraz jego jakość (56\%). Kolejno ankietowani wybierali także cenę (36\%), skład $(29 \%)$ oraz wartości odżywcze (28\%). W mniejszym stopniu zwracali uwagę na wygląd opakowania (2\%), a element działań promocyjnych miał mało istotne znaczenie w procesie wyboru wśród badanych. Cechy te zdaniem Górskiej-Warszewicz (2011) kształtują i wpływają na całościowy wizerunek marki, będący kompilacją obrazu produktu żywnościowego odzwierciedlającego cechy organoleptyczne produktu związane z percepcją fizycznych atrybutów oraz obrazu marki odzwierciedlanego poprzez atrybuty symboliczne ${ }^{24}$.

24 H. Górska -Warsewicz., Zarzadzanie markami w przedsiębiorstwach sektora żywnościowego w perspektywie długookresowej. Roczniki Naukowe SERiA, T. XVI, z. 4, s. 100. 


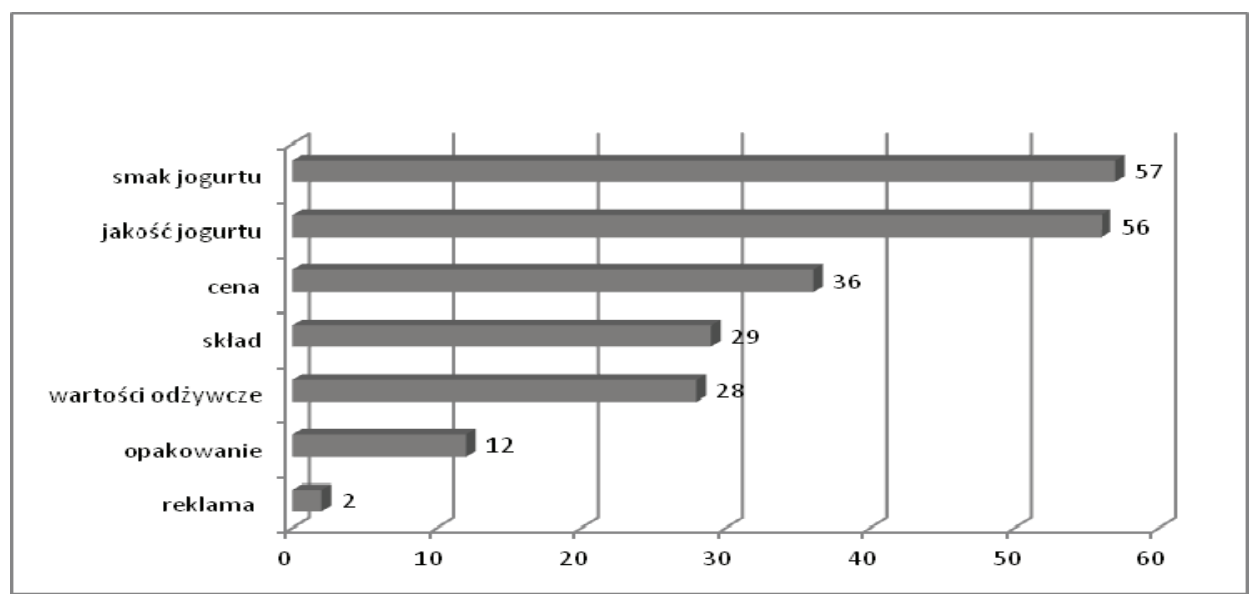

Rysunek 4. Cechy brane pod uwagę w procesie zakupu jogurtów.

Źródło: opracowanie własne na podstawie wyników badań.

Nabywcy preferują głównie jogurty owocowe i smakowe (36\%) oraz naturalne (23\%). Najrzadziej w ich koszyku zakupowym znajdują się jogurty typu greckiego (8\%). Mężczyźni wybierają więcej jogurtów pitnych niż kobiety, a w procesie zakupu i spożyciu jogurtów naturalnych głownie dominują kobiety. Uzyskane wyniki pozostają w zgodzie z innymi wynikami Autora ${ }^{25}$.

\section{Rola marki w procesie zakupu jogurtów}

Nabywcy mają konkretne oczekiwania w stosunku do markowych jogurtów. Oczekują oni, że ich wyższa cena przełoży się także na wysoką jakość. W dużej mierze liczą także na to, iż producent zachowując wysoką jakość zadba także o brak konserwantów w ich składzie. Oczekują oni, że będą to produkty posiadające wysoką powtarzalną jakość $(84 \%)$, bez zawartości konserwantów (60\%). Nabywcy oczekują także, że wyższa cena, którą płacą za markowy jogurt będzie odzwierciedleniem jego wysokiej jakości (60\%). Najmniejszą rolę wśród badanych odgrywa fakt, iż marka może być modna lub też nabywanie produktów markowych może wiązać się $\mathrm{z}$ prestiżem, czy też statusem materialnym nabywcy (4\%).

25M. Grębowiec., Znaczenie marki produktów mleczarskich w społeczeństwie informacyjnym. Marketing i rynek. Nr 11/2014 s. 165. 


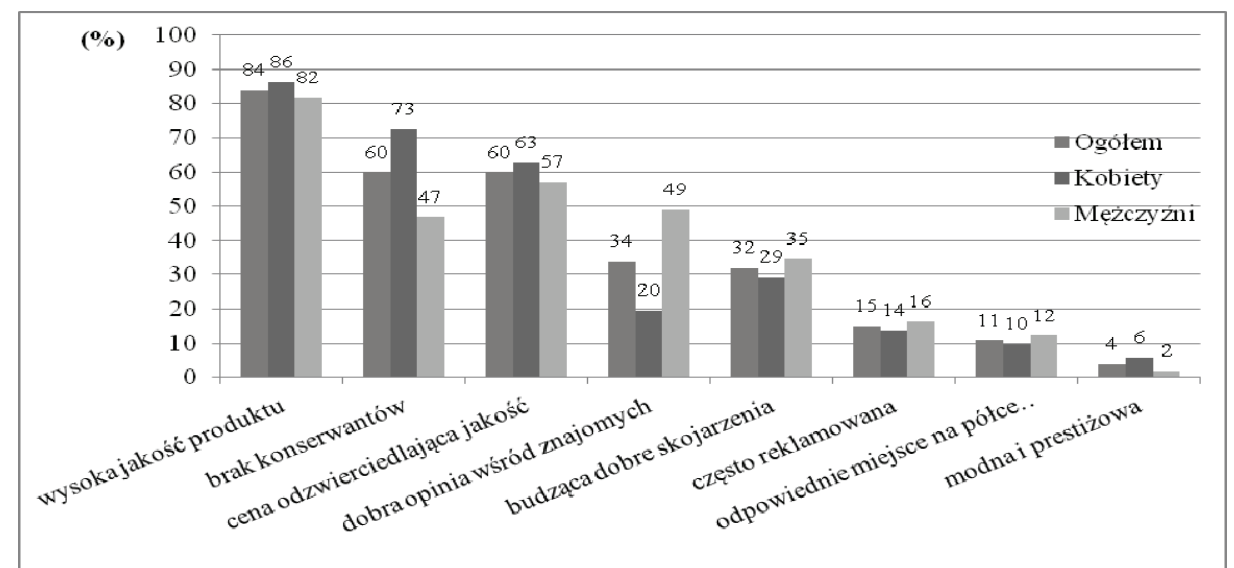

Rysunek 5. Oczekiwane cechy dobrej marki jogurtów.

Źródło: opracowanie własne na podstawie wyników badań

Nabywcy zauważają także istotne różnice między jogurtami znanych przedsiębiorstw mleczarskich, a niemarkowymi substytutami. Z łatwością dostrzegają oni różnice cenowe, gdyż nie jest konieczne zagłębianie się w szczegóły dotyczące wyrobu. Biorąc pod uwagę cechy produktu, istotną różnicą jest ich konsystencja, wyrazistość smaku oraz ilość zawartych dodatków. Istotne dysproporcje występują także w jakości opakowania. Zdaniem respondentów, jogurty markowe umieszczane są w opakowaniach wykonanych z twardszego, solidniejszego tworzywa.

Zdaniem badanych, cena jest często najbardziej zauważalną różnicą (80\%). Kolejną wymienioną przez respondentów różnicą jest wyrazistość smaku (57\%), która może być uzależniona od ilości zawartych owoców lub soków owocowych w jogurtach. Istotną różnicą jest także konsystencja jogurtów markowych $(41 \%) \mathrm{w}$ stosunku do konkurencyjnych produktów. Nabywcy rzadziej zauważają różnicę w pojemności opakowania $(10 \%)$ czy w terminie ważności (14\%). Jedynie $6 \%$ ankietowanych nie zauważyło żadnych cech różnicujących te produkty (wykres 6).

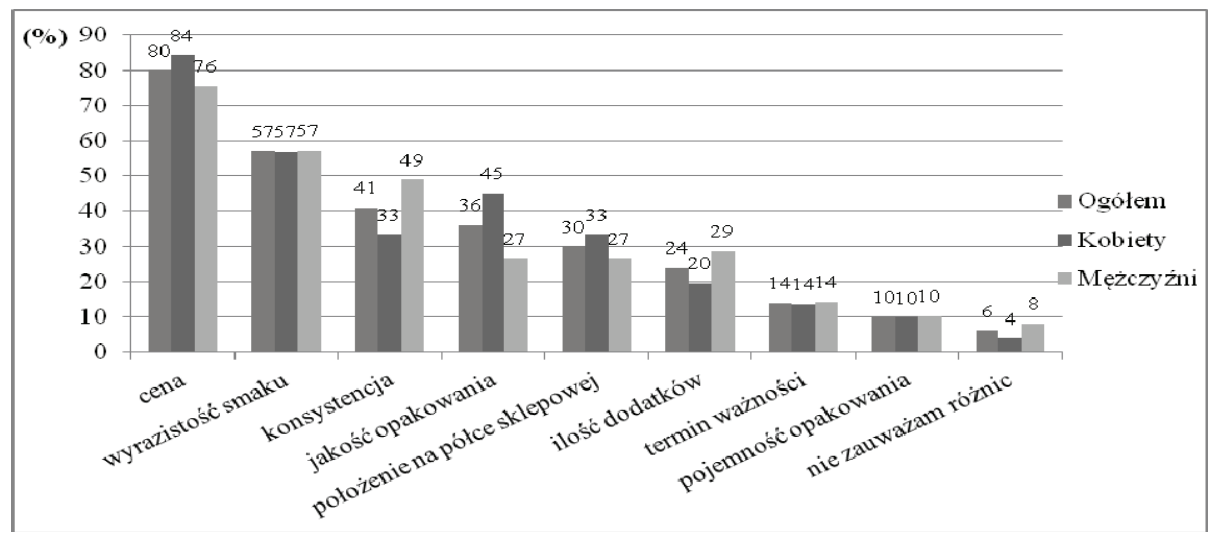

Rysunek 6. Różnice między jogurtem markowym, a nie markowym.

Źródło: opracowanie własne na podstawie wyników badań. 
$\mathrm{Na}$ zmianę ulubionej marki na markę konkurencyjną w opinii konsumentów może wpływać szereg bodźców. Do najważniejszych zaliczyć można zdaniem respondentów: spadek jakości produktu $(72 \%)$, potrzebę odkrywania przez nich nowości $(66 \%)$ oraz wzrost ceny $(63 \%)$. Najmniejszy wpływ na dokonywanie zmian mają impulsywnie dokonywane zakupy w których konsumenci nie zwracają uwagi na rodzaj wybieranego produktu. $14 \%$ ankietowanych stwierdziło, że pozostają lojalni wobec wybranej przez siebie marki i nie dokonują jej zmian.

Przywiązanie do marki może przerodzić się w lojalność konsumentów. Na przywiązanie do danej marki jogurtów najczęściej wpływa satysfakcja i zadowolenie $\mathrm{z}$ produktu. Konsumenci odczuwający satysfakcję z konsumpcji wyrobu mleczarskiego konkretnej marki nie widzą powodów do zmiany producenta. W dużej mierze na przywiązanie do marki wpływa także przyzwyczajenie nabywców i dokonywanie zakupów w sposób rutynowy, bez występowania bodźców do zmiany wybieranego asortymentu. Niekiedy zdarza się jednak, że nabywcy jogurtów decydują się na zmianę ulubionej marki.

Głównym bodźcem takiej decyzji jest spadek jakości produktu, przyczyniający się do zrodzenia się w konsumencie braku zaufania do marki. Satysfakcja i zadowolenie $\mathrm{z}$ produktu $\mathrm{W}$ największym stopniu wpływają bowiem zdaniem badanych na przywiązanie do marki (86\%). Konsumenci wskazują także na przyzwyczajenie się do wyboru danego rodzaju produktu (55\%), jak również emocjonalne przywiązanie do marki $(53 \%)$. Ponieważ dokonują oni zakupu tych produktów od szeregu lat, co świadczy o pełnym zadowoleniu $\mathrm{z}$ dokonywanego wyboru oraz o stabilności cech marki w czasie.

Spośród czołowych producentów w branży mleczarskiej najczęściej wybieraną marką jogurtów była marka Danone. Wybierało ją, aż 32\% konsumentów. Wśród popularnych marek znalazły się także Bakoma 21\% wskazań i Zott 20\%. Konsumenci wymienili także takie marki jak: Mlekovita (11\%) czy Piątnica (5\%).

\section{Podsumowanie}

Marka ma istotne znaczenie podczas dokonywania zakupów wyrobów mleczarskich. Zgodnie z wynikami przeprowadzonych badań nasuwają się wnioski potwierdzające powyższe stwierdzenie.

Konsumenci w procesie zakupowym zwracają uwagę na jakość produktów oznaczonych marką i wybierają te, dzięki którym odczuwają satysfakcję $\mathrm{z}$ zakupu. Zazwyczaj takie artykuły oznaczone są ogólnie uznanymi markami. Funkcja gwarancyjna, czyli zagwarantowanie przez producenta wysokiej jakości wyrobu spełniającego wszelkie normy, wpływa na pozytywny odbiór takich towarów przez konsumentów, co przekłada się także na ich lojalność wobec danej marki.

Głównym aspektem branym pod uwagę w czasie dokonywania wyboru jogurtu jest także jego smak. Konsumenci w dużej mierze zwracają również uwagę na jego jakość, dlatego też decydują się zapłacić wyższą cenę za oferowaną gwarancję wysokiej jakości markowych wyrobów.

Nabywcy jogurtów potrzebują także odkrywania nowości rynkowych, co daje szansę markom wchodzącym na rynek. Kluczową przyczyną zmian decyzji nabywczej, 
jest także wzrost ceny wyrobu, co zmusza konsumentów do poszukiwania tańszych substytutów.

Pomimo znaczącej częstotliwości emisji reklam promujących marki jogurtów, konsumenci nie odczuwają ich związku z dokonywaniem przez nich wyboru produktów. Reklama nie jest więc głównym bodźcem wpływającym na konsumentów i skłaniających ich do wyboru danej marki podczas dokonywania zakupów. Niemniej jednak dostarcza ona informacji o istnieniu danej marki, a jej funkcja przypominająca umacnia lojalnych konsumentów w przekonaniu co do świetności marki.

$\mathrm{Na}$ podstawie powyższych rozważań można wysnuć wniosek, że marka ma istotne znaczenie w procesie zakupu jogurtów. Wysoka jakość produktów markowych wpływa na zaufanie konsumentów do marki, a wzrost lojalności nabywców przekłada się na wzrost sprzedaży i umocnienie pozycji rynkowej przedsiębiorstwa. Producenci jogurtów, posiadający markę cieszącą się uznaniem, powinni w swoich działaniach kierować się dobrem konsumenta, gdyż od jego wyborów zależy dalszy wizerunek marek jogurtów.

\section{Literatura}

Dębski M.: Kreowanie silnej marki, Polskie Wydawnictwo Ekonomiczne, Warszawa 2009.

Górska J.: Jogurty owocowe: Mistrzowskie posunięcie, „Forum Mleczarskie Handel”, 2014, nr 6.

Górska -Warsewicz H.: Zarządzanie markami w przedsiębiorstwach sektora żywnościowego w perspektywie długookresowe, Roczniki Naukowe SERiA, 2014 T. XVI, z. 4.

Grębowiec M.: Znaczenie marki produktów mleczarskich w społeczeństwie informacyjnym, Marketing i rynek. Nr 11/2014.

Grzegorczyk A.: Reklama, Polskie Wydawnictwo Ekonomiczne, Warszawa 2010.

Kossakowska J., Sych - Winiarek J., Bochlińska E.: Spożycie przetworów mleczarskich w Polsce na tle zmian w podaży mleka, „Biuletyn Informacyjny”, ARR, Warszawa 2013, nr 4.

Kotler Ph., Armstrong G., Saunders J., Wong V.: Marketing. Podręcznik akademicki, Polskie Wydawnictwo Ekonomiczne, Warszawa 2002.

Raport Konsument na Rynku Artykułów Żywnościowych, Departament Inspekcji Handlowej UOKIK, Warszawa, Warszawa 2009.

Rudzewicz A.: Rola i znaczenie zaufania w kreowaniu marki, „Marketing i Rynek”, 2014, nr 8.

Słownik języka polskiego, t. 1, PWN, Warszawa 2007.

Świątkowska M.: Mleko - podstawa diety i gospodarki żywnościowej, „Biuletyn Informacyjny”, ARR, Warszawa 2014, nr 3.

Urbanek G.: Zarzqdzanie marka, Polskie Wydawnictwo Ekonomiczne, Warszawa 2002.

Witek - Hajduk M. K.: Zarzqdzanie silnq markq, Wyd. Oficyna a Wolters Kulwer business, Warszawa 2011.

\section{Summary}

High-quality products are appreciated by consumers. The ongoing analysis of the preferences and choices of buyers allows the perception of changes in the behavior of the market, and indicates directions of development companies. Taking into account the needs and preferences of consumers in the activities of enterprises affects the growth of their market position, as well as gaining more and more loyal customers. Brand plays a crucial role in making a selection from a wide range of market offers. The loyalty of customers towards the brand affects the increase in its reputation. This translates into an increase in sales and the possibility of further development of the company. 
Famous brands can compete on quality of customer loyalty. Using strategies to create brand image, it gains a competitive advantage.

The aim of the study was to investigate the significance of the brand among consumers when buying dairy products. As the main spectrum of interest is selected market milk and dairy products, with particular emphasis yoghurt market.

Key words: brand, dairy industry, yoghurt

\section{Informacje o autorze:}

Dr inż. Mariusz Grębowiec

Szkoła Główna Gospodarstwa Wiejskiego

W Warszawie

Wydział Nauk Ekonomicznych

ul. Nowoursynowska 166,

02-787 Warszawa

e-mail: mariusz_grebowiec@sggw.pl 